\title{
Legal and ethical responsibilities of physicians in coercive situations, such as natural disasters
}

\author{
Berna Şenel Eraslan, M.D., ${ }^{1}$ ○eytullah Karadayı, M.D., ${ }^{1} \odot$ İbrahim Eray Çakı, M.D., ${ }^{1}$ \\ (D) Naciye Aslan, M.D., ${ }^{2}$ () Ende Varlık Tokgözoğlu, M.D., ${ }^{1}$ (ㄷ Çağlayan Kılıç, M.D., ${ }^{3}$ \\ (ㄷ) Abdi Özaslan, M.D., ${ }^{1}$ ㄴ) Gürsel Çetin, M.D. ${ }^{1}$
}

\author{
1Department of Forensic Medicine, İstanbul University Cerrahpaşa Faculty of Medicine, İstanbul-Turkey \\ ${ }^{2}$ Ministry of Justice, Concile of Forensic Medicine, İstanbul-Turkey \\ ${ }^{3}$ istanbul Medeniyet University, Graduate School of Social Sciences, İstanbul-Turkey
}

\begin{abstract}
BACKGROUND: The relationship between the physician and the patient is based on the provisions of the proxy agreement. The attitude of the physician and the legal and ethical responsibilities of this attitude in an event of force majeure, such as severe natural disaster (earthquake), during a risky operation should be discussed. The aim of the present study was to present the opinions of the related professions about the subject and to discuss the subject on an ethical and legal ground.
\end{abstract}

METHODS: A total of 207 volunteers including 121 physicians working at the Cerrahpasa Faculty of Medicine at Istanbul University and 86 lawyers registered at the Istanbul Bar Association completed the questionnaires. Statistical analysis of data acquired from the questionnaires was performed using SPSS 21.0.

RESULTS: Of the participants, $76.8 \%$ stated that abandoning the patient by the physician considering his/her own safety during a severe natural disaster is ethically problematic. However, $68.1 \%$ of the participants stated that physicians would not be facing any criminal sanctions in response to his/her attitude. When the answers from both occupational groups were compared separately, it was found that $26.4 \%$ of the physicians and $39.5 \%$ of the lawyers stated that the act in question has both legal and ethical liability.

CONCLUSION: In the present study, no complete consensus was observed either between or within two occupational groups. It was concluded that the meetings in which the subject is discussed and is based on a concrete ground by both occupational groups should be held.

Keywords: Coercive situations; ethical responsibility of the physician; legal responsibility of the physician; natural disasters.

\section{INTRODUCTION}

The proxy agreement or the work contract is considered as the legal basis of the relationship between the patient and the physician. While the relationship between the patient and the physician is subjected to the work contract in aesthetic operations that would require the guarantee of the results, all the other types of relationship between the patient and the physician are subjected to the proxy agreement. ${ }^{[1-3]}$ The proxy stated in the proxy agreement is responsible for the careful efforts that he/she has undertaken in order to achieve the results, not for achieving the results. Accordingly, the physician commits to do his/her best to treat the patient and eliminates the patient's complaints but does not guarantee the result. ${ }^{[2,4,5]}$

It is known that employees in the healthcare system are very restricted in not accepting or leaving the patient. The case of not accepting the patient can come into question in the presence of trust issues. Even in these cases, according to

Cite this article as: Şenel Eraslan B, Karadayı B, Çakı İE, Aslan N, Varlık Tokgözoğlu E, Kılıç Ç, et al. Legal and ethical responsibilities of physicians in coercive situations, such as natural disasters. Ulus Travma Acil Cerrahi Derg 2018;24:440-444.

Address for correspondence: Berna Şenel Eraslan, M.D.

İstanbul Ünicersitesi Cerrahpaşa Tıp Fakültesi, Adli Tıp Anabilim Dalı, 34098 Fatih, İstanbul, Turkey

Tel: +90 212 - 4143029 E-mail: drbsenel@gmail.com 
the medical deontology regulations, the physician should not abandon the patient due to personal or professional reasons in cases of emergency, official or human duties before the treatment is completed. ${ }^{[6]}$ In cases, such as assault, violence, and verbal annoyance, that constitute trust issues within the frame of proxy agreement, the physician will, of course, face the problems, providing patient's healthcare. In such cases that are exceptional from the cases indicated in the medical deontology regulations, if the physician wishes to discontinue the treatment and follow-up his/her patient, he/she may transfer the patient to another colleague by calculating the time that will not disrupt the treatment beforehand and by notifying the patient in due time. ${ }^{[6]}$ If working in an institution, the administrators should be informed and are asked for assistance.

Even though the patients can choose the hospital and the physician to be treated within certain frames, the physician has no right to choose the patient. ${ }^{[3,7]}$ The real reason behind this is that the right to life is prioritized within the concept of the civil law. The ethical and legal responsibilities of an employee that works in the healthcare system in case of an unexpected situation that threatens his/her life should be discussed. To our knowledge, thus far, there is no regulation, doctrine, or literature present about the attitude of a physician in case of unexpected situations, such as severe natural disasters, that can harm both the patient and the physician. The aim of the present study was to present the opinions of the physicians and the attorneys and to discuss it on ethical and legal grounds.

\section{MATERIALS AND METHODS}

The study was conducted on physicians working at the Cerrahpasa Faculty of Medicine at Istanbul University and attorneys registered at the Istanbul Bar Association between January I and March 3I, 20I5. Between the indicated dates, face-to-face interviews were conducted with the physicians and the attorneys, and the participants were informed about the six-question survey entitled "Ethical and legal responsibility of the physicians in case of an event of force majeure, such as earthquake."

A total of 207 volunteers including 121 physicians and 86 attorneys expressed their verbal consents and answered the questionnaires. Face-to-face surveys were conducted to prevent repetitive participation.

The first four questions were about age, gender, profession, and duration of work in the profession and were used to determine personal information. In the next stage, the volunteers were asked to read the scenario: "A large earthquake hit during a risky operation in a hospital. Earthquake caused cracks on the walls and toppling of some items. The surgery team abandoned the building. When the team returned to the operating room they realize that the patient had died."
The volunteers were asked whether the attitude of the physician was ethically faulty in the fifth question, and whether the physician had legal and criminal liability due to his/her attitude in the sixth question.

Statistical analyses of the answers given to the questionnaires were conducted using descriptive statistics and graphical analysis tests using SPSS 21.0 (IBM). Statistical differences between the answers of the groups were analyzed using Fisher's exact test and chi-square fitness test.

\section{RESULTS}

The mean age of the 121 physicians was $37.43 \pm 11.94$ years, and $56.2 \% \quad(n=68)$ and $43.8 \%(n=53)$ of them were males and females, respectively, whereas the mean age of the 86 attorneys was $28.48 \pm 7.26$ years, and $40.7 \%(n=35)$ and $59.3 \%$ $(n=5 I)$ of them were males and females, respectively.

The professional experiences of the physicians and the attorneys were $12.58 \pm 11.96$ and $4.21 \pm 6.84$ years, respectively. The academic ranks of the physicians were $50.4 \%(n=6 I)$ as physician assistant, $18.2 \%(n=22)$ as specialist, and $31.4 \%$ $(n=38)$ as lecturer.

Of the participants, $76.8 \%$ stated that physician's abandonment of the patient considering his/her own safety during a severe natural disaster possesses ethical problems (Fig. I). Evaluation of the answers from two occupational groups revealed that $77.7 \%(n=94)$ of the physicians and $75.6 \%(n=65)$ of the attorneys found the attitude ethically wrong (Fig. 2). The answers from each occupational group were not statically significantly different $(p>0.05)$.

Of the participants, $68.1 \%(n=141)$ stated that the physician would not be faced with criminal liability due to his/her attitude (Fig. 3). However, when the answers from two occupational groups were evaluated separately, $26.4 \%(n=32)$ of the physicians and $39.5 \%(n=34)$ of the attorneys stated that the act in question has both legal and ethical liability (Fig. 4). Chisquare analysis revealed a significant difference between the answers from two groups $(p<0.05)$.

Of the physicians, $72 \%$ ( $n=85)$ were working outside of the surgical branches. The comparison of answers from the questionnaires of the physicians working in surgical branches and nonsurgical branches revealed no significant differences ( $p>0.05)$.

Of the physicians with experience $>10$ years, $91.1 \%(n=5 I)$ found the attitude ethically wrong, whereas of those with experience $<10$ years, $67.2 \%(n=43)$ found it ethically wrong. Statistical analyses between the two groups were highly significant $(p<0.01)$. Statistical analysis depending on the professional experience of the attorneys (experienced $>10$ years or $<10$ years) was not conducted as the distribution of data was insufficient. 


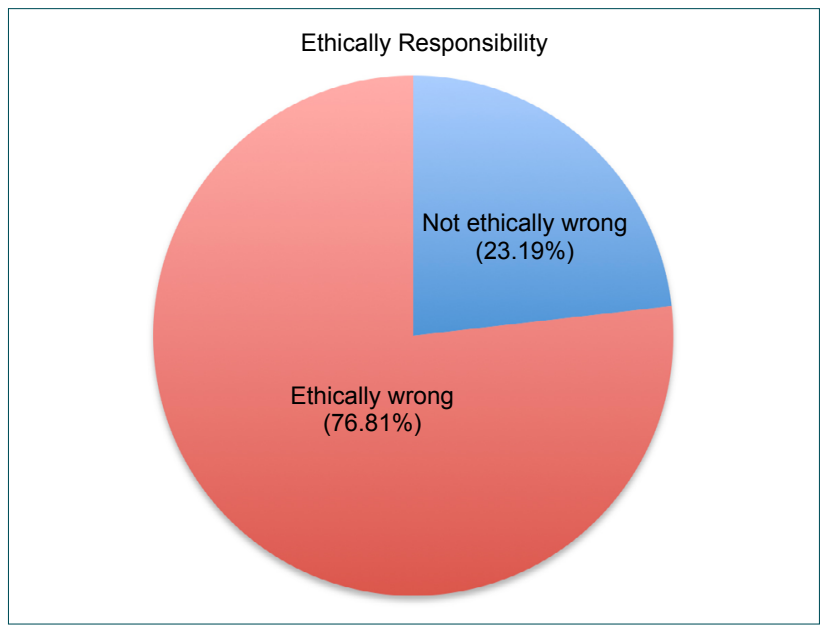

Figure 1. All participants' opinions about the ethical responsibilities of the physicians in coercive situations, such as natural disasters.

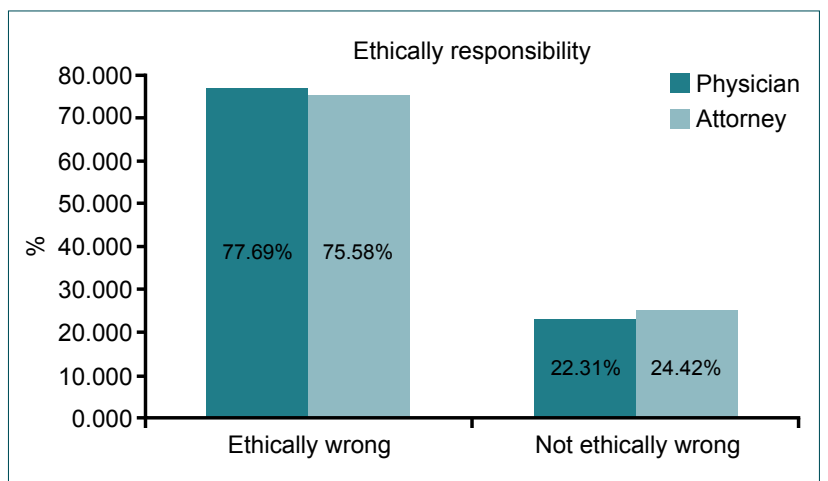

Figure 2. Doctors' and lawyers' opinions about the ethical responsibilities of the physicians in coercive situations, such as natural disasters.

\section{DISCUSSION}

All the measures taken are evaluated as the patient safety by the healthcare providers and their employees to prevent the harms that can be caused by those factors. ${ }^{[8]}$ In this context, operating rooms are complicated places where the patient's life is at risk due to intense pressure, competing with time and lack of qualified person. ${ }^{[9]}$ On the other hand, operating rooms are covered under the places where the patient's safety is the priority under natural disaster circumstances, such as an earthquake. This subject was found worthwhile to study due to the lack of doctrine, regulation, or literature about the action of the physician on duty during extraordinary situations, such as earthquakes, and conducted in order to evaluate the differences in the perspectives of the physicians and the attorneys.

In the study, the questionnaire for opinions about the legal and ethical responsibilities during coercive situations, such as an earthquake, revealed that $76.8 \%$ of the participants stated that the attitude of abandonment of the patient in the operating room is ethically wrong. However, $31.9 \%$ of the partic-

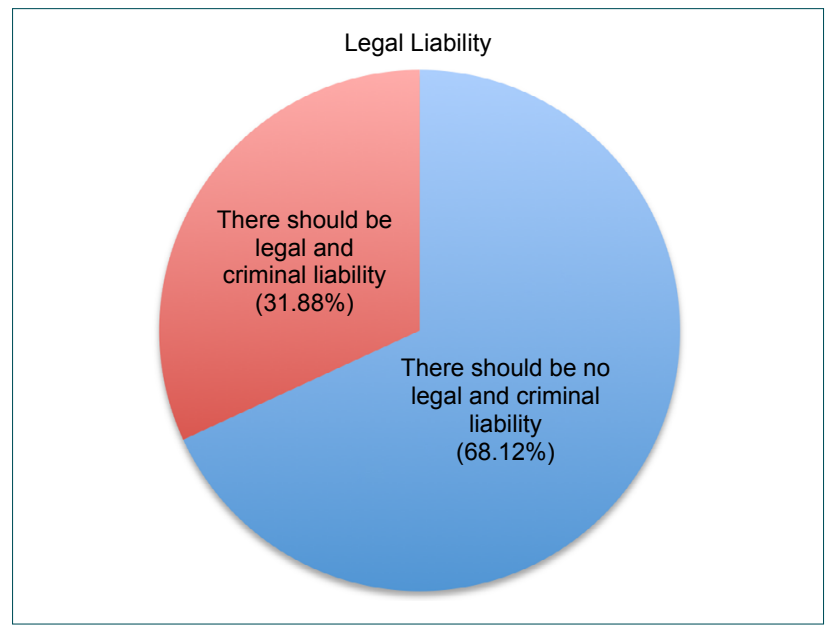

Figure 3. All participants' opinions about the legal and criminal responsibilities of the physicians in coercive situations, such as natural disasters.

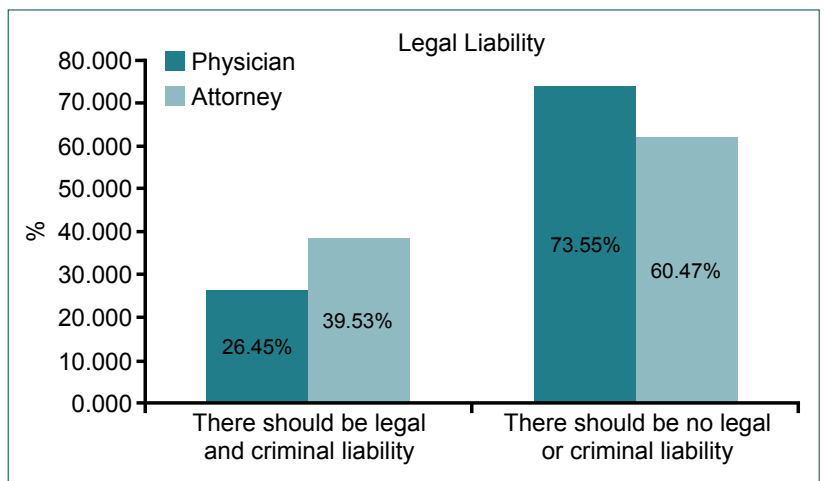

Figure 4. Doctors' and lawyers' opinions about the legal and criminal responsibilities of the physicians in coercive situations, such as natural disasters.

ipants believe that there should be a legal sanction. Thus, it is possible to state that the case creates an ethical concern rather than legal sanction by the two occupational groups. On the other hand, $77.7 \%(n=94)$ of the physicians and $76.5 \%$ $(n=65)$ of the attorneys stated that the act in question is ethically wrong. This opinion might be due to the life-threatening risk that is much higher for the patient than for the physician under surgery conditions. In addition, it might be since being a physician is raised to an unrealistic level where human life is entrusted to the physician.

There was a statistically significant difference between the two occupational groups although $26.4 \%(n=32)$ of the physicians and $39.5 \%(n=34)$ of the attorneys proposed that the attitude in question should have legal and criminal liability. We believe that the idea of the physicians is that "There should be criminal sanctions against a situation that does not comply with ethical principles of the society." is over competed by the idea of the attorneys in that "There should be a legal sanction" in the legal perspective. On the other hand, the reason of that the idea of "There should be a legal sanction" 
in the answers for the questionnaire from the physician was found to have a less opinion than the attorneys might be because the physicians act more defensive considering that they can face with such situation.

There was no statistical difference between the opinion of the physicians working in surgical branches and working in nonsurgical branches $(p>0.05)$. Although the scenario was more related with the surgical branches, the perspective did not differ statistically depending on the specialty of the physicians.

The mean age and the professional experience were found to be higher for the physicians than for the attorneys. Of the physicians with experience $>10$ years and $<10$ years, $91.1 \%$ and $67.2 \%$, respectively, found that the attitude in question was ethically wrong. Statistical analyses revealed a significant difference between the two groups. On the other hand, $55.4 \%$ and $89.1 \%$ of the experienced and inexperienced physicians, respectively, indicated that there should not be a criminal liability with a highly significant difference between the groups. We suggest that the reason of the difference about both ethical and legal liability is due to the fact that inexperienced physicians worry more than experienced ones about what they may face with such situations.

It is difficult to estimate the behavior of the individuals in case of unexpected and life-threatening conditions. The attitude of the physician varies depending on multiple parameters during the surgery where the patient's life is dependent on the surgeon in cases of coercive situations. Simultaneous and balanced introduction of different principles or rules as the guidance in the ethical dilemmas might explain the reason of the different attitudes of the physicians. ${ }^{[10]}$ It is undeniable that the physicians and other healthcare employees have a right to life as much as the patients in case of a coercive situation, such as natural disasters. In the same way, the attitude of consideration of their own safety by physicians or other healthcare employees may be perceived as protection of the most sacred, the right of life. Within the frame of the proxy agreement, it would not be possible to save or help someone else for the physician without maintaining their own safety.
In this case, the contract will die out, and this is not the expected responsibility from the health worker. ${ }^{\left[{ }^{\prime \prime}\right]}$ In the scope of the work contract, the responsibility of the health worker is heavier, and the protection of his/her own life should be admitted on the framework of the "right to life."

In the present study, no complete consensus was detected either between or within two occupational groups about the subject. We presented the evaluation in the forensic medical perspective on the attitude of the physicians in case of coercive situations. In conclusion, we believe that a detailed discussion in the meetings where both occupational groups attend would be beneficial.

\section{Conflict of interest: None declared.}

\section{REFERENCES}

1. Demir M. The Liability of Doctors under the Medicine Contract [Article in Turkish]. AÜHFD 2008;57:225-52.

2. Koç S, Yorulmaz C. Hekimin yasal sorumlulukları. In: Soysal Z, Çakalır C, editör. Adli Tip Cilt 3. İstanbul: İstanbul Üniversitesi Basımevi ve Film Merkezi; 1999. p. 45-60.

3. Hakeri H, editör. Tıp hukuku. Ankara: Seçkin Yayıncılık; 2007.

4. Erkan VU. The Obligations of the Principal Excluding the Obligation of Payment the Fee, within the context of Proxy Contracts According to the Turkish Code of Obligations No. 6098 [Article in Turkish]. AÜHFD 2013;62:441-72.

5. Altun G, Coşkun A, Yorulmaz. Yasal değişiklikler sonrası hekim sorumluluğu ve malpraktis. Trakya Üniversitesi Tip Fakültesi Dergisi 2010;27:7-12

6. Tibbi Deontoloji Nizamnamesi. Karar sayısı:4/12578, Kabul tarihi:13.01.1960, Yayın tarihi:19.02.1960.

7. Özaslan A, Kolusayın Ö. Hekimin yasal sorumlulukları. In: Adli Tip Ders Kitabı. İstanbul: İstanbul Üniversitesi Basım ve Yayınevi Müdürlüğ̈; 2011. p. 13-39.

8. Aren A. Safety of Patients and Health Workers in Operating Rooms [Article in Turkish]. İstanbul Tip Dergisi 2008;3:141-5.

9. Öğün B. Ameliyathanede hasta güvenliğinin incelenmesi. [Master Thesis]. Istanbul: Marmara Üniversitesi, Sağllk Bilimleri Enstitüsü; 2008.

10. Yıldırım G, Kadığlu S. Etik ve tıp etiği temel kavramları. C.Ü. Tıp Fakültesi Dergisi 2007;29:7-12.

11. Pulat Gözübüyük A. Mücbir sebepler beklenmeyen haller. Ankara; 1977. p. 66 . 
ORİJINAL ÇALIŞMA - ÖZET

\section{Doğal afetler gibi mücbir durumlarda hekimin hukuki ve etik sorumluluğu}

Dr. Berna Şenel Eraslan, ${ }^{1}$ Dr. Beytullah Karadayı, ${ }^{1}$ Dr. İbrahim Eray Çakı, ${ }^{1}$ Dr. Naciye Aslan, ${ }^{2}$

Dr. Ende Varlık Tokgözoğlu, ${ }^{1}$ Dr. Çağlayan Kılıç, ${ }^{3}$ Dr. Abdi Özaslan,, ${ }^{1}$ Dr. Gürsel Çetin ${ }^{1}$

${ }^{1}$ İstanbul Üniversitesi Cerrahpaşa Tıp Fakültesi, Adli Tıp Anabilim Dalı, İstanbul

${ }^{2}$ Adalet Bakanlığı, Adli Tıp Kurumu, İstanbul

3̇stanbul Medeniyet Üniversitesi, Sosyal Bilimler Enstitüsü, Tıp Hukuku, İstanbul

AMAÇ: Hekim ile hastası arasındaki ilişkinin temeli vekâlet sözleşmesi hükümlerine tabidir. Gerçekleştirdiği riskli bir ameliyat esnasında şiddetli bir doğal afet (deprem) meydana gelmesi gibi mücbir durumlarda, hekimin takınacağı tutum ve bu eylemi sonucunda hukuki ve etik açıdan sorumluluğu tartışmalıdır. Bu çalışmada ilgili meslek gruplarının bu konu hakkında görüşlerinin ortaya konulması ve bu konunun etik ve yasal zeminde tartışılması amaçlandı.

GEREÇ VE YÖNTEM: Bu çalışma kapsamında oluşturulan anket formları, İstanbul Üniversitesi Cerrahpaşa Tıp Fakültesi'nde görevli I2I hekim ve İstanbul Barosu'na kayıtlı 86 avukat olmak üzere toplam 207 gönüllü katılımcı tarafından dolduruldu. Anketlere verilen yanıtlar bilgisayar ortamında SPSS 21.0 programı kullanılarak tanımlayııı istatistik ve grafik analizi ile değerlendirildi.

BULGULAR: Katılımcıların \%76.8'i, hekimin şiddetli bir doğal afet esnasında kendi can güvenliğini düşünerek hastayı terk etmesinin etik açıdan sorun teşkil ettiğini belirtti. Ancak \%68. I'i bu davranışından dolayı hekimin herhangi bir cezai yaptırım ile karşılaşmayacağı yönünde görüş bildirdi. Anketi dolduran iki meslek grubunun yanıtları ayrı ayrı değerlendirildiğinde; hekimlerin \%26.4'ü, avukatların ise \%39.5'i söz konusu filin hukuki ve cezai sorumluluğunun bulunduğunu belirtti.

TARTIŞMA: Bu çalışma sonucunda her iki meslek grubunun birbirleri arasında ve kendi içinde bu konu hakkında tam bir görüş birliği içinde bulunmadıkları saptandı. Her iki meslek grubunun birlikte bulunduğu toplantılarda konunun tartışılması ve doğru bir zemine oturtulması gerektiği sonucuna varıldı.

Anahtar sözcükler: Doğal afetler; hekimin etik sorumluluğu; hekimin yasal sorumluluğu; mücbir sebep.

Ulus Travma Acil Cerrahi Derg 2018;24(5):440-444 doi: 10.5505/tjtes.2017.32885 